\title{
Double-Consciousness and Liminality in Ralph Ellison's Invisible Man: When African- Americans are Doomed to Live on the Borders
} Mohammed RITCHANE

\author{
Phd. Ibn Zohr University, Agadir - Morocco
}

So I denounce and I defend, and I love and I hate. Ralph Ellison Speak what you think now in hard words and tomorrow speak what tomorrow thinks in hard words again, though it contradict everything you said today Ralph Waldo Emerson

Ralph Ellison's Invisible Man is an artistic feat that testifies to the abiding presence of doubleconsciousness in African-American narratives. However, double-consciousness acquires with Ellison a more complicated dimension due, in large part, to his attempt to review the concept so as to reflect exactly the meaning intended by $\mathrm{Du}$ Bois. But while it is true that Ellison treats this concept in an ambivalent way that conjures up Du Bois' use in The Souls of Black Folk (1903), his dramatization of the concept reveals its inherent complexity in an unprecedented way. The present study purports to identify the different aspects of the novel that reflect double-consciousness and to show how doubleconsciousness is an accompanying trait of the novel in every part of it. The study will, also, indicate that Ellison's peculiar way of handling the concept in the process of its dramatization is never a mere replica of the treatment of his predecessors. In fact, Ellison's special dramatization of the concept discloses the novelist's deep and relevant understanding of it.

Invisible Man offers a rich piece of art in which double-consciousness is dramatized in an unprecedented way. In fact, the novel can be considered as an attempt at rethinking the concept of double-consciousness altogether. What seems original about Invisible Man in its connection with this concept is that its author has for the first time dramatized the concept, as will be shown, in a way that has provided a resolution for the tension of the African-American's 'warring souls'. And if there is a work of art that has best reflected as faithfully as possible $\mathrm{Du}$ Bois' concept of double-consciousness, it is unarguably Invisible Man.

The novel, which resists summation, relates in the first person point of view the story of an educated young black boy and his journey from the South to the North of
America during the pre-Civil Rights era when Blacks were denied equal treatment of Whites. Because of racis $m$, the unnamed narrator claims that he is invisible since others refuse to see him. Consequently, he chooses to live underground to ponder over his condition. This decision comes after many series of disillusionments caused by abortive attempts to integrate within an environment which refuses to recognize his individuality. A misconception of his grandfather's advice costs the narrator many hardships; unable to perceive the grandfather's saying's far-reaching irony, the narrator acts in the wrong way. On his deathbed, the grandfather's last words addressed to the narrator's father are,

Son, after I'm gone I want you to keep up the good fight. I never told you, but our life is a war and I have been a traitor all my born days, a spy in the enemy's country ever since I give up my gun back in the Reconstruction. Live with your head in the lion's mouth. I want you to overcome 'em with yeses, undermine 'em with grins, agree 'em to death and destruction, let 'em swoller you till they vomit or bust wide open. ${ }^{1}$

These words will haunt the narrator in all the stages of his life because he cannot conceive how his grandfather has qualified himself as traitor and spy, and how meekness can be a dangerous deed. The narrator owes $h$ is final uplift to the correct understanding of this saying. In fact, the grandfather's saying reveals an apparent contradiction: how can the narrator keep the good fight and 'yes' the white man at the same time? This seeming contradiction should not be surprising since it emanates from an

\footnotetext{
${ }^{1}$ - Ralph Ellison, Invisible Man (U.S.A.: Penguin Book, 1952), p. 17. Subsequent references to this edition appear in parentheses in the text under the initials $I . M$.
} 
African-A merican whose life has been conditioned by doubleness and contradictions to which he has always been submitted. The grandson's inability to grasp the meaning of the saying is attributed to his blindness to his condition as African-American, and his taking the saying at face value. Also, the grandfather's qualification of their lives as a war certainly evokes Du Bois' warring souls.

Structurally, the novel is composed of a prologue, twenty-five chapters and an epilogue; but while the prologue and the epilogue take place in the present, the twenty-five chapters are past events that the narrator is reminiscing about in his hole. His decision to live underground is built on his past experiences fraught with frustration and through which he moves from innocence to initiation. This journey is a desperate search for identity that submitted him to different sorts of humiliation and self-effacement by persons who do not care a fig about his individuality. Part of the narrator's misfortunes is attributable to his double-consciousness which endows him with two selves, a successful fusion of them is not always guaranteed. Throughout the first different stages of the novel, the narrator has always sacrificed his individuality to accommodate the others' preferences; his flaw was that he did not, in his first stages, succeed in merging successfully his two selves, his two warring souls, to use the language of Du Bois.

Invisible Man is a work of art in which a harmony between Du Bois' two warring souls is finally achieved, turning double-consciousness, ultimately, into an asset. If in Richard Wright's Native Son double-consciousness is depicted throughout the whole novel as a liability that was the direct cause of Bigger Thomas's tragedy, Ellison ends his Invisible Man by allowing his protagonist, at the end of the novel, to resolve the tension between the two opposing selves of double-consciousness. This doubleconsciousness which is at the heart of the novel is expressed by Ellison through a variety of ways that make the concept continuously reverberate throughout the whole novel. One such a remarkable way is liminality.

A salient feature of the novel that underscores double-consciousness is liminality. In fact, the interest in liminality has contributed in shedding some light on a spatiotemporal stage, which has for a long time been consigned to oblivion. The word liminality, which is derived from the Latin word limen, 'boundary' or 'threshold,' was originally coined by the French folklorist, Arnold van Gennep who used it in his work known as Rites de Passage published in 1909. But it was Victor Turner, the British anthropologist who later developed the concept in his book The Forest of Symbols: Aspects of Ndembu Ritual (1967). W ith this latter, the term acquired much breadth by its wide application to a variety of fields of recent researches. In his analysis of the concept, Turner distinguishes between three phases of liminality: a 'preliminal,' a 'liminal,' and a 'postliminal' stage, and argues that the liminal, or central, phase is the most critical of the three because it denotes a 'betwixt and between' ${ }^{2}$ phase. The importance of the liminal phase emanates from the position of the liminal persona who has left one state but has not entered a new one yet, an idea best illustrated by Robert J. Butler's declaration that "[1]iminality describes that 'betwixt and between' phase of rites of passage when an individual has left one fixed social status and has not yet been incorporated into another."’ This liminality, in the words of Victor Turner, or boundary maintenance, as Frederic Barth terms it, invades the whole novel. It is itself a source of unsteadiness because of its instability. It belongs to two sides the frontiers of which are so blurred that a clear distinction between them is as hard as the separation of the narrator's two hermetically sealed selves.

A close reading of Invisible Man will reveal that the novel is an interminable series of liminalities. These liminalities, which pervade every part of the novel, are meant to reflect doubleness in general and the narrator's double-consciousness in particular. Throughout the whole novel, the unnamed inchoate narrator is always torn between two poles. No sooner does he flee one position than he finds himself involved in a new one. To begin with, the Invisible Man's story is located between a prologue and an epilogue that serve as borders to the novel. In this respect, Berndt Ostendorf considers that "[t]he novel's Prologue and Epilogue could be read, both in form and in content, as essays on liminality and transition." ${ }^{\prime \prime}$ The prologue takes as point of departure the hole, and the epilogue returns to the same hole. The prologue and epilogue provide the novel with two liminalities, a first one at the beginning of the novel introducing the reader to the novel per se and providing the reader with information about the narrator, and a second one dealing with the Invisible Man's prospects of social reintegration after a period of hibernation. But though the prologue and epilogue serve, formally, the purpose of framing the novel, each of the two plays a radically different, if not opposite, role in the overall meaning of the novel. Though the same, the narrator of the prologue is totally different from the one in the epilogue who has gone through a process of initiation, hence the importance of these two sections which

2 - Victor W. Turner, The Forest of Symbols: Aspects of Ndembu Ritual (U. S. A.: Cornell University Press, 1967), p. 93.

3 - Robert J. Butler, The Critical Response to Ralph Ellison

(Westport: Greenwood Press, 2000), p. 81.

${ }^{4}$ - Berndt Ostendorf, "Ralph Waldo Ellison: Anthropology, Modernism, and Jazz," in: New Essays on Invisible Man. Ed. Robert G. O'M eally (New York: Cambridge University Press, 1988), p. 99. 
contribute to the understanding of the novel whose message relies heavily on the protagonist's transition, maturity and growth. In sum, the prologue and epilogue present the Invisible Man in his final stage, but the former presents the motives and the causes of the narrator's hibernation, while the latter hints at an almost final resolution. It should be underlined that both the action of the prologue and that of the epilogue occur after the events of the novel. By sharing the same temporal aspect, namely the present time, the prologue and the epilogue may be superimposed; and in being so, they emphasize simultaneity and doubleness.

At the start of the novel, and as early as the prologue, the narrator straightforwardly announces that he lives in a border, liminal area situated between Harlem and the white mainstay of the city, but belongs to neither. ${ }^{5}$ $\mathrm{He}$ is in a liminal border space which is a peculiar location, as he himself states in the first few pages of the novel: "The joke, of course, is that I don't live in Harlem, but in a border area" (I. M. p. 9).Th is situation denotes his spatial in-betweeness, being - as he is - situated between two spheres, but precisely in neither. It is a situation that allows him to be conditioned by the atmospheres of the two areas, and consequently leads him to a doubleness of perception, culminating in double-consciousness. Perhaps the narrator's invisibility is due, in some part, to his dwelling in this border area, which escapes control and justifies his siphoning electricity without being detected. Significantly, the narrator's final initiation is itself achieved in the underground, the border area, which underlines the importance of borders in the life of African-Americans. Though analyzing borders in a different context related to the colonial setting, Homi Bhabha seems to better illustrate the crucial importance of borders in Ellison's Invisible Man when he says,

These 'in-between' spaces provide the terrain for elaborating strategies of selfhood - singular or communal - that init iate new signs of identity, and innovative sites of collaboration, and contestation, in the act of defining the idea of society itself. ${ }^{6}$

This is what happens to the narrator in the novel; the new clear vision of his own existence is achieved through hibernation in the hole as a liminal space. In the hole, the Invisible Man has succeeded in defining or, rather, redefining his self as well as his social status.

\footnotetext{
5 - This idea echoes Ellison's essay "Harlem Is Nowhere," written in 1948 but remained unpublished till 1964 in which he describes the instable and contradictory life AfricanAmericans lead in the city of Harlem.

6 - Homi Bhabha, The Location of Culture (New York and London: Routledge, 1994), pp.1-2.
}

The hole is a place depicted as calm and uncontaminated by neither of the two poles that have never ceased to tear apart the narrator during his first stages before his hibernation. Ellison reverses the conception of the border area as a fixed, static place characterized by stability, and espouses the idea which holds that "[a] boundary is not that at which something stops but, as the Greeks recognized, the boundary is that from which something begins its presencing" (Italics in the text). It is the hibernation in the hole which illuminates the narrator's path, and allows him to reintegrate positively within society after having put under scrutiny all his past experiences. This hole, this border area, is seen under a positive light: "warm and full of light. Yes, full of light. I doubt if there is a brighter spot in all New York than this hole of mine, and I do not exclude Broadway" (I.M., p. 9 - Italics in the text). And "hibernation" itself which takes place only in this border area, "is a covert preparation for a more overt action" (I.M., p. 15). Hence the major importance that borders acquire with Ellison. In his underground haven, which plays the role of a sanctuary, the narrator's doubleconsciousness has attained new meaning, for he is situated in an invisible, placeless place where he has the opportunity to tune his two selves together so that he would be able to accomplish his social roles adequately. The placement of the protagonist in a border area, what Mary Louise Pratt calls "the contact zone," is meant to emphasize his duality, and consequently efface the frontiers between the two spheres which are at the origin of the segregationist behavior of the Whites, a condition which affects, largely, the destiny of the black man physically as well as psychologically.

Of all the places in the novel the cellar remains the quintessential symbol denoting the state of liminality. The narrator's recourse to this boundary area comes from his deep conviction that liminality, as a critic puts it,

Collapses the center/margin polarity, turning the boundary, the in-between space into a turbulent eddy, threatening to disrupt the traditional hierarchical arrangements. Throughout the novel, while recounting his experience, the narrator is in liminal space and time. His state of hibernation is an ambiguous synthesis of stagnancy and change. ${ }^{8}$

However, Ellis on has not waited till the end of the novel to make of his narrator a liminal character; liminality has

\footnotetext{
7 - Martin Heidegger, 'Building, Dwelling, Thinking', quoted in: Homi Bhabha, The Location of Culture (London and New York: Routledge, 1994), p. 1.

8 - Yonka Krasteva, "Chaos and Pattern in Ellison's Invisible Man,” The Southern Literary Journal, 30 (1997) , p. 56.
} 
accompanied the narrator from beginning to end. Being simultaneously African and American doomed to live in frontiers, the Invisible Man and the people of his race have always occupied liminal positions. His grandfather is introduced to the reader as being in a liminal state between life and death. This latter's liminal position is of high significance since it denotes a phase of transition between two generations of African-Americans, contributing, thus, to the reinforcement of the doubleness of the narrator who is confronted with a situation symbolizing the past which is fading but still persistently haunting him, and a new era he is about to confront. Even if the grandfather is presented only once in the novel on his deathbed, he keeps on haunting the narrator permanently during his various displacements. The shade of the grandfather constitutes only a part of the narrator's consciousness that is torn between this shade of the past and the present. The Invisible Man is attempting to get rid of the past symbolized by the death of the grandfather, but has not yet entered a new safe phase of life, the situation becoming complicated by his grandfather's ambiguous saying which, at least ostensibly, evokes duplicity: "I want you to overcome 'em with yeses, undermine 'em with grins, agree 'em to death and destruction, let 'em swoller you till they vomit or bust wide open" (I.M. p. 17).

What is peculiar about the narrator, as far as liminality is concerned, is that when he thinks that he has left a liminal state, finds himself in front of a new one until his fall in the cellar, the final liminality; he is always torn between two poles. His life is a series of liminalities. Hardly does he leave a condition, a classification or a state than he confronts another, and this liminal state he occupies engenders his invisibility. This is what is meant by Turner when he asserts that the "'subject of passage ritual is, in the liminal period, structurally, if not physically, "invisible." 9 After leaving the college, the narrator becomes socially unclassified, situated between the hope of returning to the college and his journey to the North. Though he left the college physically, he remained obsessed with it, encouraged by the seven letters of recommendation handed to him by Dr. Bledsoe, the college president.

The narrator's heading north increases his condition of double-consciousness, because he has remained in a state of liminality between the past and the present despite his departure from the South. His aspiration towards leadership forces him to attempt to forget his past during his search for new horizons; but this attempt is baffled by many reminders of his past, a past reminding him of the impossibility of shedding the past, being as it is, an

\footnotetext{
9 - Turner, The Forest of Symbols, p. 95
}

important constituent of his identity. Throughout the whole novel, the Invisible Man is presented as torn between the past and the present in an overlapping manner, and "the novel constantly provides echoes of past eras within the narrative present." 10 The narrator lives in the present with reminiscences from the past echoed by his grandfather's voice. Here, there is a temporal doubleness, a temporal liminality, which is a perennial characteristic accompanying the nameless protagonist, and contributing to the persistence of his doubleconsciousness.

In addition to the suitcase and the letters of recommendation that still bind him to the college and keep on situating him between a past and a present situation; during his journey, the narrator encounters many reminders that keep him in constant contact with his past. While getting in the train heading north, he comes across the vet whom he met earlier in the Golden Day, and whose speech is no less ambiguous than that of the narrator's grandfather. On his arrival to Harlem, and in spite of the larger scope of freedom, the narrator cannot get rid of his double-consciousness easily, because still living in a liminal phase, torn between two opposed poles, his past evoked by the reminders that conjure up slavery and racis $m$ and his present auguring boundless hope. This buttresses the claim that double-consciousness is not related only to the South or any other place where racis $\mathrm{m}$ is manifest, but rather to the African-A mericans' historical heritage that is indelibly inscribed in their psyche.

In the North, the reminders abound; there is first the meeting with Peter Wheatstraw who is typically southern in every respect. It is not coincidental that during this meeting, known as the Wheatstraw episode, the cartman makes use of scriptio continua, in whichwordswere writtenwithoutspace. The cartman asserts,

"I'maseventhsonofasevenths onbawnwithacauloverbotheye sandraisedonblackcatboneshighjohntheconquerorandgreas ygreens -" (I.M. p. 144), a declaration which, structurally, attempts to efface borders and creates a kind of word linkage, reflecting Wheatstraw's, and by extension the narrator's strivings to join their two selves. Wheatstraw's declaration, also, refers unequivocally to Du Bois' famous as sertion that

the Negro is a sort of seventh son, born with a veil, and gifted with second-sight in this American world - a world which yields him no true self-consciousness, but only lets him see himself through the revelation of the other world. (Souls, p. 7)

\footnotetext{
10 - Marc Singer, “'A Slightly Different Sense of Time:' Palimpsestic Time in Invisible Man." Twentieth Century Literature, 49 (2003), p. 390.
} 
It is to be concluded from the narrator's meeting with the cartman that the African-American's heritage cannot be erased by a simple desertion of the area in which this heritage has burgeoned. Rather, the African-American's past accompanies him permanently, because it is an essential part of his identity which is inherently double, composed of two indivisible parts.

The past for the narrator, and for all AfricanAmericans, acquires its importance from its being the crucible of the crucial events of their history. Coupled with the present, they both give birth to, or at least enhance, double-consciousness. One instance of emphasizing the importance of preserving the past as an indispensable constituent of the African-American's identity is the link in Tarp's iron leg handed to the narrator and which stands as a memory from the past and its unspeakable terrors. '"I'd like to pass it on to you There,' he [Brother Tarp] said, handing it to me. 'Funny thing to give somebody, but I think it's got a heap of signifying wrapped up in it and it might help you remember what we're really fighting against. I don't think of it in terms of but two words, yes and no; but it signifies a heap more..."' (I.M. p. 313 - Italics in the text); the link, as its name suggests, is a gift intended to emphasize the importance of the preservation of memory and the past, and to link the past to the present. As for Du Bois, Douglass, Toni Morrison and other notable AfricanAmericans, the past - in spite of its unspeakable terrors, or perhaps because of them - should, in no way, be ignored or glossed over because it remains an integral part of the African-American's essence. These artists have always been ready to express themselves through the lens of the past, an idea corroborated by Fanon who "recognizes the crucial importance, for subordinated peoples, of asserting their .... cultural traditions and retrieving their repressed histories."11

More than a series of events to ruminate on, the past for the Invisible Man, especially after his self-discovery, serves as a road map that guides him and prevents him from repudiating his culture, while remaining ready to embrace other views that preach inclusion. Everything that refers to the past is not a badge of shame, as it is propagated by the supremacist to blur or erase the other's identity, and as it is thought by the narrator in his first stages; the past is a precious nostalgia that contains events seldom registered in history. Many characters in the novel are associated with the past, but Mary Rambo is recognized by the protagonist as "a stable familiar force like something out of my past which kept me from whirling off into some unknown which I dared not face"

\footnotetext{
${ }^{11}$ - Bhabha, The Location of Culture, p. 9.
}

(I.M., p. 258). The past is, in this sense, a modulator that contributes to the maintenance of the African-A merican's psychical equilibrium.

In its fusion with the present, the past becomes among the crucial instigators that generate the peculiar state Du Bois labels double-consciousness, this peculiar experience of the African-American which cannot be objectively perceived except by those who experienced it. Torn between the burden of his past and the exigencies of his present, the narrator feels lost and keeps on oscillating between two opposing situations, hardly reconcilable; it is a condition that favors and exacerbates the feeling of double-consciousness. As for the past and the present and their close relatedness in Invisible Man as well as their connection with double-consciousness, Anselm Maria Sellen advances,

In fact the "dualistic whole" [past and present and all the other opposites that form dualities] that constitutes the narrator's identity has gained the strength Du Bois has said to be inherent to the doubleconsciousness and about which I have spoken in my analysis of the hospital episode: The double-consciousness becomes a source of strength. ${ }^{12}$

The protagonist in the novel serves as a tool for the reconciliation of many dissident parts. In addition to the fact that he reconciles parts of history that are, according to the historical records written by the supremacists, irreconcilable, he always mediates between two opposing temporal poles, attempting to merge them.

Though in Harlem, the narrator is always haunted by the past; he cannot escape his double-consciousness because he often confronts overt racism in the North as in the South; the waiter in the restaurant, out of racial prejudice, offers him a Southern meal to awaken him of his daydreams and to remind him that racism is ubiquitous and so is his double-consciousness. On his arrival to Harlem, a voyage meant - among other things to change the narrator's life altogether through leaving his past behind him, the Invisible Man is still kept between two worlds, and the reader "senses in Invisible Man a profound portrait of the suspension between what Arthur P. Davis called "two worlds": a world of segregation "not yet dead" and a world of integration "not fully born.",13 When the narrator meets Peter Wheatstraw, the cartman,

\footnotetext{
12 - Anselm Maria Sellen, Fooling Invisibility - A Bakhtinian Reading of Ralph Ellison's "Invisible Man:" Applying Bakhtinian Theory to Ralph Ellison's "Invisible Man" (Germany: Grin Verlag, 2010), pp. 89-90.

13 - Michael D. Hill, Lena M. Hill, Ralph Ellison's Invisible Man: A Reference Guide (Westport: Greenwood Press, 2008), p. 142.
} 
this latter reminds him, once again, of the past the narrator strives to forget. "I thought you was trying to deny me at first, but now I be pretty glad to see you ..." (I.M., p.144), the cartman tells the narrator. Also, the songs the cartman sings in the presence of the narrator all bind the narrator to his bygone days when he used to hear them at school, and remind him that his past is as near to him as his present.

But it is the narrator's skin which is, above all, the most concrete reminder of his being black American because his past and his origins are inscribed on his skin. His colour will never allow him to put aside his heritage. This fact creates a kind of frustration for the narrator who has thought that his journey to the North will free him of his past complexes. It turns out that the others' behaviour towards him is determined by his pigmentation which positions him on the verge of two situations, a situation he is really in, and a situation to which he aspires and with which he attempts to forget the past injuries incurred by racis $m$. Though in the heart of Harlem, the narrator is located within the claws of his Southern heritage. When the Invisible Man has left Wheatstraw, the cartman, to enter a drugstore, the counterman spontaneously offers him "the special," made up of "Pork chops, grits, one egg, hot biscuits and coffee" (I.M., p.145), an act which distresses the narrator because it is the typical menu offered to Blacks. The narrator considers this act prejudicial, partly because it reminds him of his past and its tragical segregationist attendants.

All these reminders that the unnamed narrator encounters are meant to prove to him that he has not crossed the color line yet and that he is always in a liminal state that exacerbates, ineluctably, his doubleconsciousness. In every part of Harlem, the narrator always meets people of his caste or objects that make him revive his past. When introduced at Liberty Paints, he finds figures of the South like Lucius Brockway whose presence confirms, among other things, the indissociable selves of the African-Americans. Brockway, as many other African-Americans the narrator meets in Harlem, may stand as the narrator's African self. More important in the factory is the incident that the narrator goes through when he loses consciousness because of the explosion during his struggle with Brockway. This struggle can be interpreted as a struggle with the narrator's past; and it is ironical that the narrator recovers only after hearing stories of his black past heritage. The incident of the factory plays a major role in triggering off the protagonist's hidden and latent past. At this moment, the Invisible Man's past experiences are revived, rekindled, and given a free rein. Like a purgatory, the block in the factory serves to eliminate the blurred vision of the narrator. "It was as though in this short block," says the
Invisible Man, "I was forced to walk past everyone I'd ever known" (I.M., p. 357). The incident in the factory serves, also, to revive all past experiences from a present stance, the very adequate narrative technique that suits the condition of African-A mericans and which is adopted by Ellison.

Mary Rambo, the woman who nurses the narrator and shelters him after his experience in the factory, stands as another prominent reminder. She insinuates to the narrator that he has not totally broken with his past, and that he still occupies a liminal state. It is to be emphasized that the narrator is welcome by Mary at the very time when he has been rejected by Harlem and its exploitative dimension embodied by the Liberty Paints Factory. That Mary is a symbol of the past is unquestionable. In her home the Invisible Man recovers the high values of the South. And it is also important that the narrator decides to embrace the Brotherhood when he is living with Mary, after a long hesitation. The narrator's indecision towards enrolling with the Brotherhood is another indication of $h$ is two warring selves as well as of his inability to successfully merge these two selves at this stage of his life.

Also, the old couple, Primus Provo, whom the policemen want to evict serves as another reminder of the narrator's in-between position. The incident literally brings back the past to the narrator and stirs in him memories from that past, to remind him that he is still in a position of betweenness. All of the old couple's possessions revive and rekindle the narrator's past, because they invoke memories related to slavery and racis $m$ that still have bold imprints on all AfricanAmericans. The following passage in which the narrator ponders over the old couple's possessions is highly revealing of this fact, and is worth quoting in its entirety, for it minutely depicts the extent to which the past is entrenched in the African-American's psyche. Perusing the old couple's possessions, the narrator intimates,

I turned away, bending and searching the dirty snow for anything missed by my eyes, and my fingers closed upon something resting in a frozen footstep: a fragile paper, coming apart with age, written in black ink grown yellow. I read: FREE PAPERS. Be it known to all men that my negro, Primus Provo, has been freed by me this sixth day of August, 1859. Signed: John Samuels Macon ... I folded it quickly, blotting out the single drop of melted snow which glistened on the yellow page, and dropped it back into the drawer. My hands were trembling, my breath rasping as if I had run a long distance or come upon a coiled snake 
in a busy street. It has been longer than that, further removed in time, I told myself, and yet I knew that it hadn't been. I replaced the drawer in the chest and pushed drunkenly to the kerb.

But it wouldn't come up, only a bitter spurt of gall filled my mouth and splattered the old folk's possessions. I turned and stared again at the jumble, no longer looking at what was before my eyes, but inwardlyoutwardly, around a corner into the dark, far-away-and-long-ago, not so much of my own memory as of remembered words, of linked verbal echoes, images, heard even when not listening at home. (I.M., pp. 220221 - Italics in the text)

These reminders that stubbornly keep reminding the narrator of his past, and consequently of his liminality and double-consciousness, constitute both a retrieval of freedom and an encroachment on it. They pervade the novel and are manifested through a variety of ways, especially symbolism. The symbols referring to the past are legion in the novel, and play the specific role of insisting on the importance of the past for the AfricanAmerican wherever he goes. In this sense, the narrator's psychical equilibrium depends on his ability to make his two selves interact dynamically in a harmonious way. Undoubtedly, the reminders stand as recalcitrant opponents against the narrator's disavowal of his past heritage which forms a major part of his identity; his grandfather's advice, the briefcase, the shackles, and the letters of recommendation, to name but a few, are elements of his past experiences that cannot be erased easily. The invasion of the narrator's present by his past experiences serves to duplicate his self which becomes torn between two temporalities, a past which has become like an accompanying shadow, and a present that is open to every eventuality. All in all, double-consciousness which is a permanent condition can be heightened or exacerbated by all these reminders.

The narrator's flaw is his attempt to sacrifice, by all means, his precious past which is an indispensable part of his self to achieve success even by erasing his identity and individuality, hence his unquestioning accommodation in the first stages of his life; his major aim is to be recognized by the decision-makers. This is one of the fundamental themes in Ellison's Invisible Man. As James B. Lane puts it, “Ellison's fundamental assumption in Invisible Man was that black people became recognizable only when they suppressed their real self and conformed to emasculating parodies of the white man's self-contradictory image of them." ${ }^{14}$ From the first pages of the novel, what matters most for the Invisible Man is to earn the approval of the persons embodying power; he bears the humiliation and dehumanization of his race in a self-effacing manner, for the sake of impressing the white trustees. In no stage of his life is the narrator his own choice maker, for he easily accepts and unquestioningly acquiesces to the whims imposed on him in an attempt to seek some advantages that would entitle him to rank among the privileged. This becomes more apparent when he embraces the Brotherhood, an organization which pretends to uplift the condition of the marginalised. The change of the narrator's name which remains undivulged, the change of his dwelling, and the significant change of his clothes are just attempts to slough off his heritage, especially that the outer forces find the narrator ready to be stripped of this heritage. The narrator's self is shattered by the two conflicting demands of the past and the present; this self has to achieve a balance between these two aspects dictated by both the past and the present.

In fact, there are memorable scenes in the novel in which Ellis on blends the past with the present in an attempt to reflect the duality invading the protagonist. Often, images from the past are reiterated in front of the narrator in the present time as reminders of his past. A good example is the beginning of chapter sixteen in which the past and the present almost overlap. Ellis on begins this chapter with the narrator encountering a picture of a boxer blinded in the ring; this image is clearly remin iscent of the Battle Royal of chapter one, as it serves, principally, to remind him of his past, especially related to his own father who has already told the narrator this same story of how the same boxer was blinded. The present image and the past story evoke in the narrator a special feeling of sadness. In the beginning, the Invisible Man does not want to acknowledge that his past memories are as important and as invigorating as his present situation. It is noteworthy that the past itself is doubly handled, for it serves two contradictory purposes; while it is a means by which the protagonist achieves a certain equilibrium for his unhealthy psyche by remembering the joyful bygone days, it is also an inescapable part of the life of the protagonist which keeps on erupting involuntarily to remind him of the harsh reality of racism. "There was no escaping such reminders" (I.M., p. 141), the narrator says, an assertion which implies that there is an attempt to vainly escape such reminders and the harm they cause.

As far as borders, spatial as well as temporal, are concerned, no doubt the Invisible Man is Ellison's alter

\footnotetext{
14 - James B. Lane, "Underground to Manhood: Ralph Ellison's Invisible Man," Negro American Literature Forum, St. Louis University, Vol. 7, No. 2 (Summer, 1973), p. 65.
} 
ego. And even if Ellison asserted, on more than one occasion, that the novel is far from being autobiographical, the similarities between some aspects of the unnamed narrator's life and Ellison's are striking. In his self-depiction as a frontiers man doomed to borders because of his dichotomous heritage, the narrator resembles Ellison's family. Many analogies between the Invisible Man and Ellison can be easily drawn; and though it is not the concern of this study to explore the autobiographical dimension of the novel, it is illuminating, however, to say that the narrator's situation resembles Ellison's situation in more than one respect:

Born in Oklahoma in 1914 to parents who had migrated there a few years after statehood (1907) hoping the new state would embrace the values of frontier possibility more than those of the Jim Crow South, young Ellison experienced both worlds. ${ }^{15}$

It is the destiny of all African-Americans whose identity is continuously shattered to live on the borders. AfricanAmericans are not oblivious of this fact and keep on struggling to attain a certain equilibrium for their warring selves. The Invisible Man expresses this hope as follows: "If only all the contradictory voices shouting inside my head would calm down and sing a song in unison, whatever it was I wouldn't care as long as they sang without dissonance; yes, and avoided the uncertain extremes of the scale. But there was no relief" (I.M., p. 211). No surprise, then, if Ellis on blends the two temporal dimensions of past and present to erase the frontiers, temporal as well as spatial, in the hope that he might overcome the shattering of his two selves pulled apart between the present and the past. This temporal inbetweenness is expressed by Harold Bloom in the following words:

Ellison inherits a double obligation to the past. He must become familiar with a folk tradition which is his alone, and with a wider literary culture which he shares. Moreover, he must strive in both dimensions for a proper blend of past and present, given and improvised. ${ }^{16}$

The conflation of the past and the present appears to be one of the means by which Ellis on attempts to merge the two selves of the protagonist who is doomed to doubleconsciousness, but tries to escape a precious part of his self, namely his past. This is perhaps why at the end of the

15 - John F. Callahan, Ralph Ellison's Invisible Man: A Casebook (New York: Oxford University Press, 2004), p. 7.

16- Harold Bloom, Ralph Ellison's Invisible Man (Philadelphia: Chelsea House, 1999), p. 7. novel, in his final epiphany, the protagonist "starts to connect the separate moments of his life, to see how events in the past inform and resurface in his present, to perceive time as a palimpsest." ${ }^{\prime 17}$ It is this blending of the past and the present that is behind the existence of the narrator's final indispensable equilibrium of doubleconsciousness as he is constrained to think, act, and reason dually, a condition which cannot be successfully achieved except by the blending of his two selves torn between the past and the present.

Though determined to discard his past, the narrator appears to be always fettered by fragments of this past, which are often triggered off by the multiple encounters with the men of his race. Had he the possibility to easily get rid of his past, the narrator would act unilaterally according to the exigencies of the present. But being perpetually haunted by the past and its attendants, he has to simultaneously act according to this past as well as to his present. This is one of the consequential lessons the narrator apprehends at the end of the novel. Illustrating this point, Marc Singer declares,

Ellison's protagonist also learns that the past is not a set of isolated moments but rather a continuity of events, merging with themselves and with the present to form a synchronic whole. He is a product and, in many ways, an incarnation of this eternally present, synchronic time, for Ellison posits that identity is an amalgamation of experiences over time and a constant negotiation with the past. ${ }^{18}$

It is necessary to emphasize that the narrator's plight is the result of his being of African origin, or rather, black and American whose past is heavily loaded with peculiar events that cannot be rubbed off by a stroke of a pen. It is this past in its rivalry with the present that creates the permanent psychical duality for the African-American. This duality is judged to be at the very core of the novel's tension in its various manifestations. Ellis on's aim behind writing the novel is from the very outset well mapped out, convinced that a person with traits of an AfricanAmerican cannot be depicted but in terms of duality. Consequently, he - as an artist especially - should not ignore the duality inherent to his self, because "this double consciousness lies at the heart of African American artistic production." ${ }^{19}$ It is a fact of which

\footnotetext{
17 - Marc Singer, “'A Slightly Different Sense of Time:' Palimpsestic Time in Invisible Man," Twentieth Century Literature, 49 (2003), p. 398.

18 - Ibid., p. 410.

19 - William Lyne, "The Signifying Modernist: Ralph Ellison and the Limits of the Double Consciousness," PMLA 107 (1992), p. 319
} 
Ellison was deeply convinced, especially that he, like Du Bois and Douglass before him, never allowed himself to fall prey to historical amnesia and throw into oblivion his past which is a valuable part of his life.

Indeed, "Ellison embraces the multicultural richness of his heritage, and we can see in all his work the artistic potential in the double consciousness"; 20 and by so doing, he refused to sacrifice any of the two selves composing, necessarily, the African-A merican self. Ellison seems to be highly aware of the feeling resulting from the experience of double-consciousness exactly as it is delineated by Du Bois; this is why Robert "Stepto regards Invisible Man as the apotheosis of the African American tradition of 'ascent' and 'immersion' narratives that has its first full flowering in DuBois." 21 The African heritage is unquestionably, then, an indiv isible part of the AfricanAmerican's double-consciousness through which he struggles to cope with his peculiar condition in A merica. It is in this peculiar condition of being in-between, spatially and temporally, that the African-A merican's self find a sort of equilibriu m, because for him "[e]very v ision must be double, must be, for example, both integrationist and nationalist." 22

The fusion of the past and the present is often achieved in the novel through retrospection. The importance of retrospection lies in the fact that it allows the narrator to simultaneously bring together the past and the present. As a matter of fact, the novel is but a recurrent shift from present to past and vice versa through retrospection either wakefully or in dreams. Among the most remarkable retrospections is the narrator's dream in which the grandfather asks him to open his briefcase and read the engraved document written in documents of gold wherein it is written, "To Whom It May Concern. Keep This Nigger-Boy Running" (I.M., p. 32). It is, also, of high significance that the document is put within an envelope, itself put within another envelope, both of them put in a third one, which connotes the double, or even triple, aspect of the destiny of the African-American, for the document is really part and parcel of the black boy's destiny. The document may, also, refer to the inscription inscribed in the hidden psyche of the black boy which is governed by more than one intervening force.

\section{REFERENCES}

[1] Bhabha, H. K. (1994). The Location of Culture. New York and London: Routledge

[2] Bloom, H. (1999). Ralph Ellison's Invisible Man. Philadelphia: Chelsea House

[3] Butler, R. J. (2000). The Critical Response to Ralph Ellison. Westport, Connecticut: Greenwood Press

[4] Callahan, J. F. (2004). Ralph Ellison's Invisible Man: A Casebook. New York: Oxford University Press

[5] Ellison, R. (1952). Invisible Man. U.S.A.: Penguin Book

[6] Heidegger, M. (1994). 'Building, Dwelling, Thinking.' In: Homi Bhabha. The Location of Culture.London and New York: Routledge

[7] Hill, M. D. and Lena, M. H. (2008). Ralph Ellison's Invisible Man: A Reference Guide. Westport: Greenwood Press.

[8] Krasteva, Y. (1997). “Chaos and Pattern in Ellison's Invisible Man.” The Southern Literary Joumal, 30, $1-55$.

[9] Lane, J. B. "Underground to Manhood: Ralph Ellison's Invisible Man."

[10] Lyne, W. (1992). "The Signify ing Modernist: Ralph Ellison and the Limits of the Double Consciousness." PMLA, 107, 319-330.

[11] Ostendorf, B. (1988). "Ralph Waldo Ellison: Anthropology, Modernism, and Jazz." In: New Essays on Invisible Man. Edited. Robert G. O. New York: Cambridge University Press

[12] Reed, T. V. (1992). Fifteen Jugglers, Five Believers: Literary Politics and the Poetics of American Social Movements. U.S.A.: University of California Press

[13] Sellen, A. M. (2010). Fooling Invisibility - A Bakhtinian Reading of Ralph Ellison's "Invisible Man:" Applying Bakhtinian Theory to Ralph Ellison's "Invisible Man." Germany: Grin Verlag

[14] Singer, M. (2003). "“A Slightly Different Sense of Time:' Palimpsestic Time in Invisible Man." Twentieth Century Literature Vol. 49, Issue 3, 388419.

[15] Turner, V. W. (1967). The Forest of Symbols: Aspects of Ndembu Ritual. U. S. A.: Cornell University Press

\footnotetext{
${ }^{20}$ - Ibid., p. 320.

${ }^{21}$ - Ibid., p. 320.

22 - Thomas Vernon Reed, Fifteen Jugglers, Five Believers: Literary Politics and the Poetics of American Social Movements (U.S.A.: University of California Press, 1992), p.86.
} 